DOI: https://doi.org/10.24144/2409-6857.2020.1(55).112-117

УДК 658:351.863]:004.7

Пойда-Носик Н.Н., Мазютинець Г.В.

\title{
ЗАСТОСУВАННЯ ШТУЧНИХ НЕЙРОННИХ МЕРЕЖ ДЛЯ АНАЛІЗУ РІВНЯ ФІНАНСОВОЇ БЕЗПЕКИ КОМПАНІЙ
}

\begin{abstract}
У статті розкрито сутність використання математичних моделей, а саме штучних нейронних мереж для аналізу рівня фінансової безпеки підприємств. Описано процедуру автоматизації нейронної мережі. Описано прочедуру відбору показників підприємств для аналізу рівня фінансової безпеки. Представлено порядок визначення кодових значень для нейромережі. Проаналізовано підприємства за різними показниками та виведено рівень фінансової безпеки для кожного з них. Співставлено розрахункові дані n'яти підприємств протягом 10 років у зведеному вигляді. Доведено адекватність моделі нейронної мережі.
\end{abstract}

Ключові слова: фінансова безпека компанї; акціонерні товариства; штучні нейронні мережі; математичні моделі.

Постановка проблеми. В останні десятиліття в економіці багатьох країн спостерігається істотне збільшення кількості фінансових криз і зростання їх масштабів. Чого вартує глобальна фінансова криза 2020 року, яка є найбільшою 3 часів великої депресії і 2008 року, проявилася у падінні світового фондового ринку та поштовхом якої став коронавірус SARS-CoV-2, що вразив усі країни світу. Глобальна фінансова криза 2020 року супроводжується зменшенням ділової активності у багатьох галузях та відповідним падінням ВВП у багатьох країнах. Це свідчить про те, що існуючі теорії фінансового аналізу і методи прогнозування розвитку фінансовоекономічних систем практично себе вичерпали. Тому постає потреба істотного переосмислення використовуваних методів економікоматематичного моделювання. Вчені схиляються до використання нейронних мереж, які вважаються одним 3 найбільш відомих та ефективних інструментів інтелектуального аналізу даних.

Оскільки бурхливий розвиток комп'ютерної техніки створює передумови для появи нейрокомп'ютерів, які, за прогнозами фахівців будуть обробляти інформацію за тими ж принципами, що і людський мозок [1], то інтерес до нейромережевих технологій поступово

(c) Пойда-Носик Н.Н., к.е.н., проф., професор кафедри фінансів і банківської справи ДВНЗ «Ужгородський національний університет», м.Ужгород, e-mail: nina.nosyk @uzhnu.edu.ua

Мазютинець Г.В., аспірант кафедри інформаційних управляючих систем та технологій, провідний інженер-програміст Центру інформаційних технологій ДВНЗ «Ужгородський національний університет», м.Ужгород, e-mail: gabbi.maz@uzhnu.edu.ua охоплює все більш широке коло користувачів.

Серед таких користувачів опинилися фінансові аналітики та архітектори фінансових систем компаній, про що свідчать широкі дискусії у фінансових чатах щодо ефективності застосування нейромереж для прогнозування фінансових показників.

Аналіз останніх досліджень і публікацій. Найчастіше нейронні мережі використовуються у працях Kuan C., White H., Swanson N. та інших науковців для прогнозування фінансових ринків. Garcia R., Genfay R., Qi M. i Madala G. обгрунтували корисність нейронних мереж для аналізу трендів на фондовому ринку, а Jorion P. для прогнозування валютного курсу. Нейронні мережі у працях вітчизняних науковців, таких як Н.Я.Савка, О.Ф.Івашина, І.І.Стрельченко, А.Б.Миколайчук та ін., більшою мірою застосовуються для прогнозування рівня фінансової безпеки держави та окремих іiі складових (податкової, боргової, у розрізі рівнів регіону). На рівні суб'єктів підприємництва досі залишається незавершеним вивчення питань застосування нейронних мереж для аналізу та прогнозування рівня фінансової безпеки.

Мета статті полягас у дослідженні особливостей використання нейронних мереж для аналізу рівня фінансової безпеки компаній.

Опис основного матеріалу дослідження. Нейронні мережі виникли із досліджень у галузі штучного інтелекту, а саме зі спроб відтворити здатність біологічних нервових систем навчатися й виправляти помилки, моделюючи низькорівневу структуру мозку. Штучні нейронні мережі являють собою нову й досить перспективну обчислювальну технологію, що дає нові підходи до дослідження динамічних завдань у фінансовій області. Спочатку нейронні мережі відкрили нові можливості в області розпізнавання 
образів, потім до цього додалися статистичні і засновані на методах штучного інтелекту засоби підтримки прийняття рішень і вирішення завдань у сфері фінансів, у тому числі для діагностики банкрутства підприємства.

В сучасних економічних умовах діяльність підприємств знаходиться під впливом перманентних ризиків та загроз, які генеруються факторами зовнішнього та внутрішнього середовища їх функціонування. Найбільша кількість ризиків та загроз притаманна саме акціонерній формі господарювання. Тому надзвичайно важливим $\epsilon$ аналіз рівня фінансової безпеки $з$ точки зору попередження виникнення загроз та своєчасності застосування превентивних заходів.
Вирішення задач аналізу рівня фінансової безпеки акціонерних компаній за допомогою нейронних мереж складається з наступних етапів: пошук даних для навчання; підготовка i нормалізація даних; вибір типу нейронної мережі; експериментальний підбір характеристик мережі; експериментальний підбір параметрів навчання; навчання штучної нейронної мережі; перевірка адекватності навчання; коригування параметрів; кінцеве навчання; вербалізація нейронної мережі для іiї подальшого використання.

Графічно нейронну мережу для прогнозування рівня фінансової безпеки компанії можна зобразити наступним чином (рис. 1).

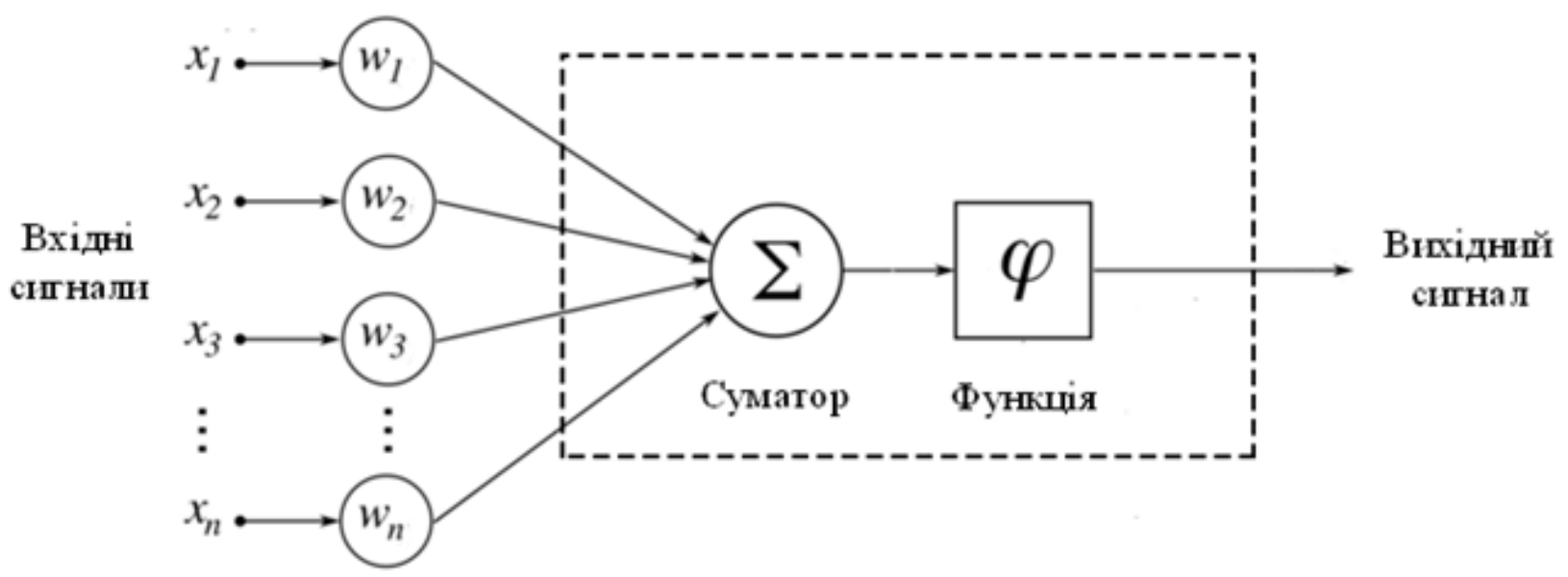

Рис. 1. Графічне зображення нейронної мережі [3]

Процедура автоматизації нейронної мережі наступна. Як видно з рис. 1, під час роботи мережі до вхідних елементів подаються значення вхідних змінних $x_{1}, x_{2}, x_{3}, \ldots x_{n}$, що являють собою фінансові показники діяльності підприємства. Кожен показник має свою вагу $w_{1}, w_{2}, w_{3}, \ldots w_{n}$, яка визначається за нормативним значенням. Суматор підраховує середнє арифметичне ваг вхідних сигналів $\frac{\sum_{i=1}^{n} w_{i}}{n}$. Після чого функція активації відпрацьовує подані дані - результат проходить через певні нормативні значення і на виході з мережі ми отримуємо рівень фінансової безпеки підприємства.

В якості вхідних даних нейронної мережі слугуватимуть індикатори. Індикатори, або показники стану фінансової безпеки, - це характеристики стану фінансової діяльності, відібрані для характеристики стану фінансової безпеки підприємства. Для останньої важливе значення мають як самі індикатори, що характеризують фінансовий стан, так i їхні порогові значення. Під пороговими значеннями індикаторів фінансової безпеки доцільно розуміти граничні величини, недотримання яких призводить до переходу фінансової безпеки 3 безпечного стану до небезпечного. Слід підкреслити, що за межами граничних значень індикаторів фінансової безпеки фінансова система підприємства втрачає спроможність до динамічного розвитку, стає об'єктом, який втрачає свою ліквідність, тому їй загрожує банкрутство. Одні показники є кількісними i вимірюються або в натуральних, або у відсоткових величинах, а інші - якісними.

Для вхідних параметрів нейромережі була сформована система показників, яка включає кількісні показники (відносні, вартісні, динамічні) та якісні показники (табл.1). По факту, ставилося завдання вибудувати числову систему показників, яка відобразить всі необхідні вхідні параметри для оцінки рівня фінансової безпеки компанії і прийняття рішень на перспективу. 
Якісні та кількісні показники, які закладені в методику, були ретельно відібрані на основі нормативних документів та праць вітчизняних $\mathrm{i}$ зарубіжних авторів, а також на основі опитування керівників підприємств. Для кожного показника визначено кодоване значення для нейромережі, залежно від діапазону нормативних значень та напряму зміни в динаміці.

\section{Система показників для нейромережевого прогнозування рівня фінансової безпеки} акціонерних товариств*

\begin{tabular}{|c|c|c|}
\hline Групи показників & Назва вхідного параметра (змінної) & $\begin{array}{c}\text { Діапазон зміни вхідного } \\
\text { параметра та його кодовані } \\
\text { значення для нейромережі }\end{array}$ \\
\hline \multicolumn{3}{|c|}{ І. ВІДНОСНІ ПОКАЗНИКИ: } \\
\hline \multirow[t]{5}{*}{$\begin{array}{l}\text { 1.1.Показники } \\
\text { фінансової стійкості: }\end{array}$} & $\begin{array}{l}\text { 1. Коефіцієнт фінансової незалежності “автономії” } \\
\text { (Кавт) }\end{array}$ & $\begin{array}{r}\geq 0,5-5 \\
0,3-0,5-3 \\
0,1-0,3-1 \\
\end{array}$ \\
\hline & 2. Коефіцієнт фінансової стабільності (Кф.с.) & $\begin{array}{c}>1-5 \\
0,5-1-3 \\
0,1-0,5-1\end{array}$ \\
\hline & 3. Фінансовий ліверидж (Фа) & $\begin{array}{c}\text { Більше } 1-5 \\
\text { Менше } 1-1 \\
\text { (якщо ВС }>\text { Рентаб.), у протилежному } \\
\text { випадку - навпаки } \\
\end{array}$ \\
\hline & 4. Коефіцієнт забезпечення власними коштами (Кз.к.) & $\begin{array}{l}>0,1-5 \\
<0,1-1 \\
\end{array}$ \\
\hline & $\begin{array}{l}\text { 5. Коефіцієнт покриття необоротних активів власним } \\
\text { капіталом (К4 - з методики) }\end{array}$ & $\begin{array}{l}>1-5 \\
<1-1\end{array}$ \\
\hline \multirow[t]{3}{*}{$\begin{array}{l}\text { 1.2. Показники } \\
\text { ліквідності }\end{array}$} & 6. Коефіцієнт покриття (Кл) & $\begin{array}{l}\text { Більше } 2-5 ; \\
0,5-1-2 ; 1-1,5-3 ; 1,5-2-4 \\
\quad \text { до } 0,5-1 \\
\end{array}$ \\
\hline & $\begin{array}{l}\text { 7. Коефіцієнт швидкої (проміжної) ліквідності } \\
\text { (Кш.л.) }\end{array}$ & $>0,7-5$ \\
\hline & 8. Коефіцієнт абсолютної ліквідності (Ка.л) & $\geq 0,2-5$ \\
\hline \multirow{9}{*}{$\begin{array}{l}\text { 1.3.Показники ділової } \\
\text { активності }\end{array}$} & 9. Коефіцієнт оборотності активів (Ко.а) & $\begin{array}{l}\text { Збільшення - 5; } \\
\text { Зменшення - } 1\end{array}$ \\
\hline & 10. Коефіцієнт оборотності оборотних активів $\left(\mathrm{K}_{9}\right)$ & $\begin{array}{l}\text { )Збільшення - } 5 \text {; } \\
\text { Зменшення - } 1 \\
\end{array}$ \\
\hline & 11. Середня тривалість одного обороту активів (Чо.а) & $\begin{array}{l}\text { Збільшення - } 1 \\
\text { Зменшення - } 5\end{array}$ \\
\hline & 12. Коефіцієнт оборотності запасів (Ко.з) & $\begin{array}{l}\text { Збільшення - 5; } \\
\text { Зменшення - } 1\end{array}$ \\
\hline & 13. Середня тривалість одного обороту запасів (Чо.з) & $\begin{array}{l}\text { Збільшення - } 1 \\
\text { Зменшення - } 5\end{array}$ \\
\hline & $\begin{array}{l}\text { 14. Коефіцієнт оборотності дебіторської } \\
\text { заборгованості (Ко.д) }\end{array}$ & $\begin{array}{l}\text { Збільшення -5 } \\
\text { Зменшення - } 1\end{array}$ \\
\hline & $\begin{array}{l}\text { 15. Середній період погашення дебіторської } \\
\text { заборгованості (Чо.д) }\end{array}$ & $\begin{array}{l}\text { Збільшення - } 1 \\
\text { Зменшення - } 5\end{array}$ \\
\hline & $\begin{array}{l}\text { 16. Середній період погашення кредиторської } \\
\text { заборгованості (Чо.кр) }\end{array}$ & $\begin{array}{l}\text { Зменшення або збільшення (залежить від } \\
\text { попереднього показника) } \\
\end{array}$ \\
\hline & $\begin{array}{l}\text { 17. } \mathrm{K}_{10} \text { - коефіцієнт оборотності позичкового } \\
\text { капіталу за фінансовими результатами від звичайної } \\
\text { діяльності (ЕBITDA) }\end{array}$ & $\begin{array}{c}\text { Збільшення - 5; } \\
\text { Зменшення - } 3 \\
\text { Від’ємне значення - } 0\end{array}$ \\
\hline \multirow[t]{4}{*}{$\begin{array}{l}\text { 1.4.Показники } \\
\text { рентабельності }\end{array}$} & 18. Рівень рентабельності продажу (реалізації) (Рр.) & $\begin{array}{c}\text { Збільшення - 5; } \\
\text { Зменшення - } 3 \\
\text { Від'ємне значення - } 0 \\
\end{array}$ \\
\hline & $\begin{array}{l}\text { 19. } \mathrm{K}_{6} \text { - коефіцієнт рентабельності продажу за } \\
\text { фінансовими результатами від операційної } \\
\text { діяльності (ЕВIT) }\end{array}$ & $\begin{array}{c}\text { Збільшення - 5; } \\
\text { Зменшення - } 3 \\
\text { Від’ємне значення - } 0 \\
\end{array}$ \\
\hline & $\begin{array}{l}\text { 20. } \mathrm{K}_{7} \text { - коефіцієнт рентабельності продажу за } \\
\text { фінансовими результатами від звичайної діяльності } \\
\text { (EBITDA) }\end{array}$ & $\begin{array}{c}\text { Збільшення - 5; } \\
\text { Зменшення - } 3 \\
\text { Від'ємне значення - } 0 \\
\end{array}$ \\
\hline & 21. Рівень рентабельності активів (Ра) - К8 & $\begin{array}{c}\text { Збільшення - 5; } \\
\text { Зменшення - } 3 \\
\text { Від’ємне значення - } 0\end{array}$ \\
\hline
\end{tabular}




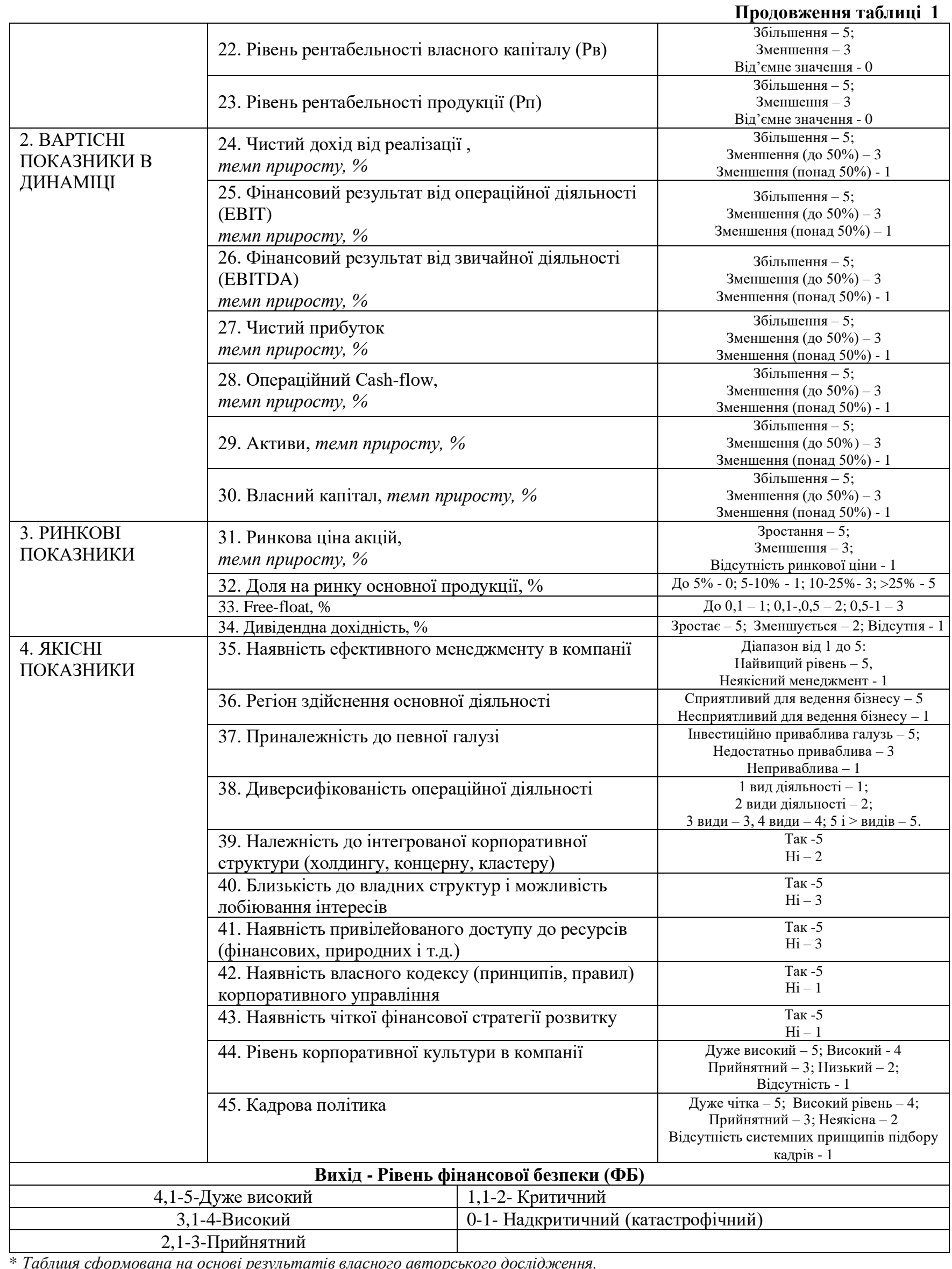


Для проведення аналізу рівня фінансової безпеки за допомогою нелінійних математичних методів, а саме штучних нейронних мереж було вибрано 5 підприємств: ПАТ «Мотор Січ», ПАТ «Укртелеком», ПАТ «Центренерго», ПАТ «Укрнафта», ПАТ «Крюківський вагонобудівний завод». Ці підприємства протягом досліджуваного періоду складали основу індексного кошику ПФТС, в який включаються найбільш ліквідні акції фінансово стабільних підприємств.

Процедура дослідження показників складалася
3 формування вибірки даних 3 фінансової звітності на сайті www.smida.gov.ua по кожному підприємству протягом 2008-2018 років; розрахунок відібраних індикаторів; відслідковування інформації з відкритих джерел (аналітичні огляди, відгуки, публікації, результати маркетингових досліджень, дані фондових бірж).

Результати ретроспективного моделювання значень показника рівня фінансової безпеки відібраних для аналізу акціонерних товариств України наведені у табл.2 та на рис.2.

Таблиця 2

Результати розрахунку рівня фінансової безпеки акціонерних товариств в Україні із застосуванням методу штучних нейронних мереж за період 2009-2018 роки*

\begin{tabular}{|l|c|c|c|c|c|c|c|c|c|c|}
\hline & 2009 & 2010 & 2011 & 2012 & 2013 & 2014 & 2015 & 2016 & 2017 & 2018 \\
\hline ПАТ «Мотор Січ» & 4,83 & 4,25 & 3 & 4,17 & 3,67 & 3,33 & 4,08 & 2,83 & 4,17 & 2,83 \\
\hline ПАТ «Укрнафта» & 2,67 & 4,08 & 3,83 & 2,83 & 3,5 & 3,92 & 2 & 1,42 & 3,29 & 2,67 \\
\hline ПАТ «Укртелеком» & 4,17 & 3,54 & 3,75 & 4 & 2,58 & 3,17 & 2,58 & 2,5 & 2,67 & 2,92 \\
\hline ПАТ «Центренерго» & 1,88 & 4 & 2,92 & 3 & 2,67 & 2,25 & 2,33 & 3,42 & 4 & 4 \\
\hline $\begin{array}{l}\text { ПАТ «Крюківський } \\
\text { вагонобудівний } \\
\text { завод» }\end{array}$ & 2,83 & 4,92 & 4,42 & 3 & 2,75 & 2,75 & 2,58 & 4,33 & 4,67 & 4,42 \\
\hline
\end{tabular}

* Результати власних авторських досліджень

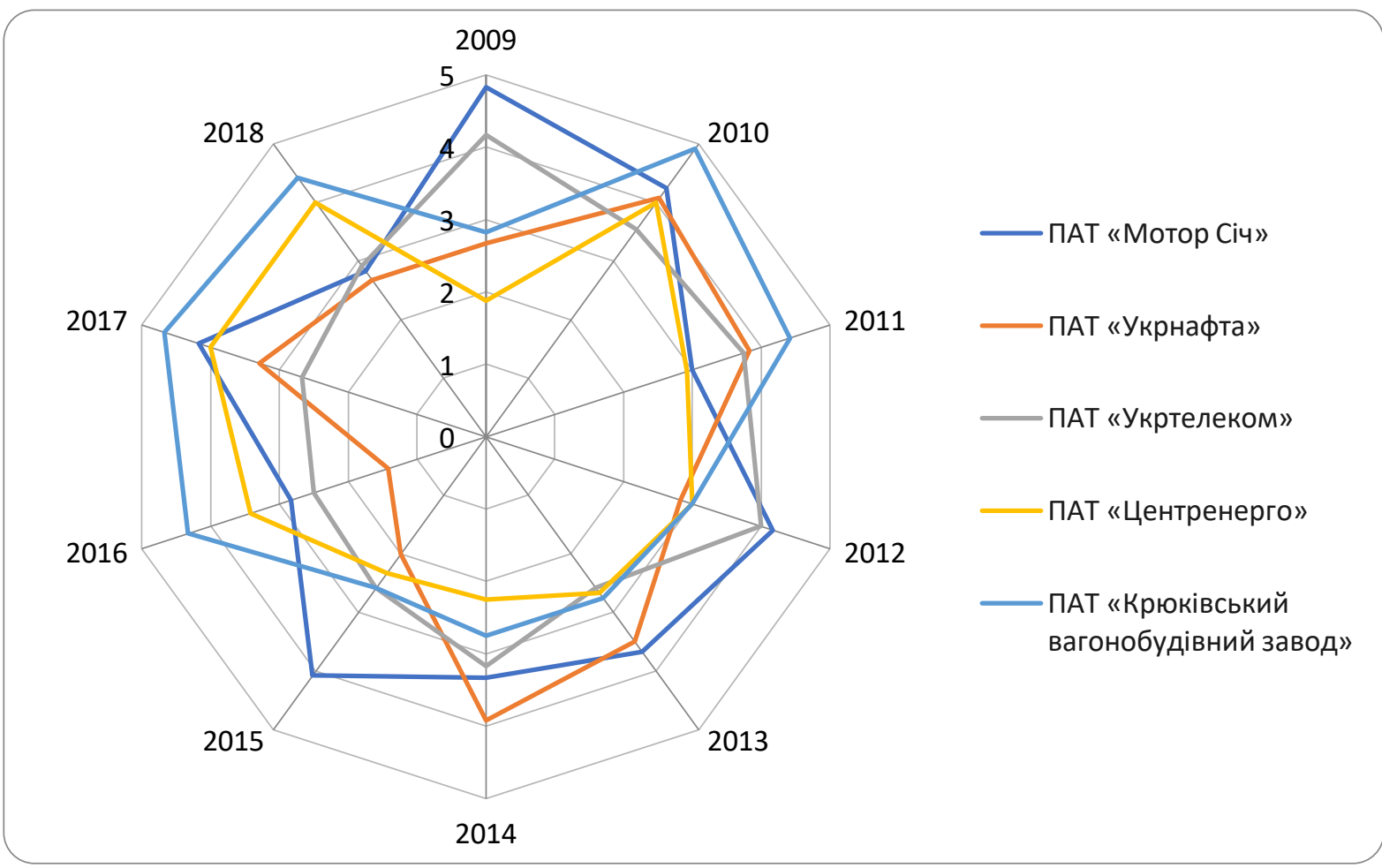

Рис.2. Динаміка рівня фінансової безпеки акціонерних товариств в Україні (графічне представлення даних табл.2)

Результати розрахунків вказують, що серед відібраних п’яти підприємств найвищий рівень фінансової безпеки протягом всіх років мав ПАТ «Крюківський вагонобудівний завод», другу 
позицію у рейтингу займає ПАТ «Мотор Січ». Найнижчий сукупний рівень фінансової безпеки зафіксовано у 2015 році. Це пояснюється тим, що у попередньому, 2014 році, Україна стикнулась із найбільшими у 21-му столітті викликами, включно із економічною кризою, військовим конфліктом на Сході, анексією Криму Росією. Падіння внутрішнього попиту та слабкий зовнішній попит спричинили падіння реального ВВП на 6,8\% [3]. Криза 2014 року стала причиною пониження рівня фінансової безпеки багатьох вітчизняних суб'єктів господарювання, у тому числі й досліджуваних підприємств.

Висновки i перспективи подалыших досліджень. Таким чином, результати досліджень оцінки рівня фінансової безпеки на основі застосування штучних нейронних мереж довели адекватність застосовуваної моделі. Доцільність застосування нейронних мереж для оцінки рівня фінансової безпеки акціонерних товариств обумовлена тим, що часто дані не мають певної лінійної залежності або $є$ неповними, тому в таких випадках слід використовувати штучні нейронні мережі. Перспективи подальших досліджень у даному напрямку можуть стосуватися більш чіткого математичного обгрунтування виділених рівнів фінансової безпеки, а також особливостей врахування змінних факторів для перспективного прогнозування за допомогою нейромереж.

\section{ПЕРЕЛІК ВИКОРИСТАНИХ ДЖЕРЕЛ}

1. Чаркин Е.И. Стратегическое развитие информационных технологий и связи // Автоматика, связь, информатика. 2017. №4. С. 2-5

2. Нейронные сети. STATISTICA Neural Networks: Методология и технологии современного анализа данных / [под редакцией В. П. Боровикова]. — 2-е изд., перераб. и доп. — М. : Горячая линия — Телеком, 2008. $-392 \mathrm{c}$

3. 2014 рік: Економічні підсумки для України / Публікація Інституту економічних досліджень та

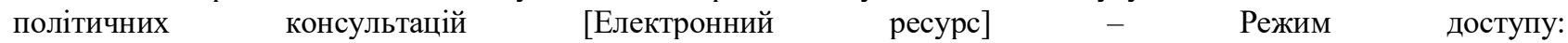
http://www.ier.com.ua/ua/publications/regular_products/economic_results_of_year?pid=4954

\section{REFERENCES}

1. Charkin, E.I. (2017). Strategic development of information technologies and communications [Stratehycheskoe razvytye ynformatsyonnыkh tekhnolohyi y sviazy]. Automation, communications, informatics - Avtomatyka, sviaz, ynformatyka, 4, 2-5 [in Russian].

2. Borovikov, V.P. (Eds.) (2008). Neural networks. STATISTICA Neural Networks: Methodology and technology of modern data analysis [Neironnye sety. STATISTICA Neural Networks: Metodolohyia y tekhnolohyy sovremennoho analyza dannykh]. M.: Hot line - Telecom [in Russian].

3. Economic results for Ukraine [Ekonomichni pidsumky dlia Ukrainy] (2014). Publication of the Institute for Economic Research and Policy Consulting - Publikatsiia Instytutu ekonomichnykh doslidzhen ta politychnykh konsultatsii. $\quad$ Retrieved from: http://www.ier.com.ua/ua/publications/regular_products/economic_results_of_year?pid=4954 [in Ukrainian]. 